\title{
The Analysis of Load and Need Factor for Roomboy at Housekeeping Department New Idola Hotel Jakarta
}

\author{
Ika Suryono Djunaid \\ Sekolah Tinggi Pariwisata Bogor \\ Bogor, Indonesia \\ koko_aufklarung@rocketmail.com
}

\begin{abstract}
This study aimed to determine how much workload given to room boy and labor productivity in the Housekeeping Department room boy New Idola Hotel Jakarta. The study consisted of two indicators of workload analysis and needs room boy namely: the amount of work (number of rooms) and working time (per hour). This research is descriptive quantitative research. The population of this research is the data room occupancy on the number of uninhabited rooms, check out the number of rooms uninhabited rooms along with the percentage derived from the Housekeeping Department of New Idola Hotel Jakarta. The study concluded that the main tasks of this research are room boy clean room uninhabited (occupied), check out the room, and the room is empty on one section (morning shift). The use of productive work time based room boy given workload is over 360 minutes. Ideal number of requirements in Housekeeping Department room boy New Idola Hotel Jakarta is 11 people in one section on the morning shift.
\end{abstract}

Keywords - room boy, workload.

\section{INTRODUCTION}

Hotel is one of accommodation for people who travel for a variety of purposes. Company's hotel consists of buildings that can be used partially or completely to organize an accommodation, food and drink and other services.

One very important part in the housekeeping department of a hotel is because it is a part of the duty and responsibility to maintain the cleanliness, neatness and comfort throughout the hotel area both inside and outside the building. The general meaning of housekeeping by Sugiarto and Sri Sulartiningrum (1993: 203), "Housekeeping is one part that is inside the hotel which deal with matters relating to beauty, tidiness, cleanliness, completeness entire room is also the whole area other common for all guests and employees can feel safe and comfortable in the hotel ".

The operational part is very important to note in the Housekeeping Department Floor Section is a skilled workforce, honest and has extensive knowledge in order to do a good job especially roomboy clerk in charge of cleanliness, neatness and beauty of the rooms. According Rumekso (2002: 7) roomboy can be defined as the person in charge of keeping, caring for, cleaning and tidying guest rooms to be clean, complete, beautiful, and comfortable. In cleaning and maintaining the hotel rooms to be sold and satisfy the guests, roomboy play an important role for smoothness, cleanliness and hotel revenues. Therefore, the extent of the guests staying at the hotel was very influenced by the condition of the rooms are managed by roomboy. Workloads that are not in accordance with roomboy work productivity will have an impact on employment roomboy of less optimal results.

According to Sugianto was quoted by Suwatno and Priansa (2011: 251) that:

"Workload contains basic concepts available energy usage and energy reserves. The task is seen heavy (overload) if the main energy has been used and still have to use energy reserves to complete the task. Instead, a task taken lightly (underload) if the main energy is still abundant after the task is completed.'

According to Agus Tulus (1996: 49), that the analysis of the workload can be calculated from the amount of work to be done and then divided by how much work an employee can be completed. Then reported the amount of labor required.

\section{METHOD}

This research is descriptive quantitative research. The population of this research is the data room occupancy on the number of uninhabited rooms, check out the number of rooms uninhabited rooms along with the percentage derived from the Housekeeping Department of New Idola Hotel Jakarta. The study concluded that the main tasks of this research are room boy clean room uninhabited (occupied), check out the room, and the room is empty on one section (morning shift).

\section{RESULT}

After pre-field observations, the authors look at Executive Housekeeper divide several sections for 7-8 people roomboy every day. Section contains a number of rooms to be cleaned roomboy on that day and must be completed. One section roomboy get $17-18$ rooms to be cleaned. This causes roomboy fixated on how to clean these rooms without have to wasting time in it, because there are many rooms must be cleaned. It also causes less maximum employee performance, so the quality of the maintenance of cleanliness of the guest rooms are not maintained properly in accordance with specified standards and it can be concluded that the rooms that will be sold in the 
state is not ready, and impacts on their guest complaints about the condition of the rooms.

According to Agus Sulastiyono (2011: 130), with the number of room's available 182 units needs 15 room attendant. It means if the 182 rooms available, then it should be a hotel to have 15 room attendant in one shift to clean the room optimally in accordance with the standards and procedures that have been given.

At the time of initial survey in New Idola Hotel Jakarta there are only 11 people roomboy amount to 180 the number of available rooms. Based on the above can be concluded that the discrepancy between the number roomboy with the number of hotel rooms to be cleaned. This is due to the presence of the standard provisions the amount of labor which performing a particular task. This problem resulted in less maximal work of housekeeping employees and non-performance of work efficiency in order to increase the marketability of the room. Therefore, measurement of workload needs to be redone to determine the number of employees who actually needs.

The purpose of this research is to determine how much the workload given to roomboy and labor productivity in the Housekeeping Department roomboy New Idola Hotel Jakarta. Furthermore to describe the ideal number roomboy needs by measuring the workload in the Housekeeping Department New Idola Hotel Jakarta.

Hotel is one of accommodation for people who travel for a variety of purposes. Company's hotel consists of buildings that can be used partially or completely to organize an accommodation, food and drink and other services.

One very important part in the housekeeping department of a hotel is because it is a part of the duty and responsibility to maintain the cleanliness, neatness and comfort throughout the hotel area both inside and outside the building. The general meaning of housekeeping by Sugiarto and Sri Sulartiningrum (1993: 203), "Housekeeping is one part that is inside the hotel which deal with matters relating to beauty, tidiness, cleanliness, completeness entire room is also the whole area other common for all guests and employees can feel safe and comfortable in the hotel ".

The operational part is very important to note in the Housekeeping Department Floor Section is a skilled workforce, honest and has extensive knowledge in order to do a good job especially roomboy clerk in charge of cleanliness, neatness and beauty of the rooms. According Rumekso (2002: 7) roomboy can be defined as the person in charge of keeping, caring for, cleaning and tidying guest rooms to be clean, complete, beautiful, and comfortable. In cleaning and maintaining the hotel rooms to be sold and satisfy the guests, roomboy play an important role for smoothness, cleanliness and hotel revenues. Therefore, the extent of the guests staying at the hotel was very influenced by the condition of the rooms are managed by roomboy. Workloads that are not in accordance with roomboy work productivity will have an impact on employment roomboy of less optimal results.

According to Sugianto was quoted by Suwatno and Priansa (2011: 251) that:
"Workload contains basic concepts available energy usage and energy reserves. The task is seen heavy (overload) if the main energy has been used and still have to use energy reserves to complete the task. Instead, a task taken lightly (underload) if the main energy is still abundant after the task is completed."

According to Agus Tulus (1996: 49), that the analysis of the workload can be calculated from the amount of work to be done and then divided by how much work an employee can be completed. Then reported the amount of labor required.

After pre-field observations, the authors look at Executive Housekeeper divide several sections for 7-8 people roomboy every day. Section contains a number of rooms to be cleaned roomboy on that day and must be completed. One section roomboy get 17-18 rooms to be cleaned. This causes roomboy fixated on how to clean these rooms without have to wasting time in it, because there are many rooms must be cleaned. It also causes less maximum employee performance, so the quality of the maintenance of cleanliness of the guest rooms are not maintained properly in accordance with specified standards and it can be concluded that the rooms that will be sold in the state is not ready, and impacts on their guest complaints about the condition of the rooms.

According to Agus Sulastiyono (2011: 130), with the number of room's available 182 units needs 15 room attendant. It means if the 182 rooms available, then it should be a hotel to have 15 room attendant in one shift to clean the room optimally in accordance with the standards and procedures that have been given.

\section{CONCLUSION}

At the time of initial survey in New Idola Hotel Jakarta there are only 11 people roomboy amount to 180 the number of available rooms. Based on the above can be concluded that the discrepancy between the number roomboy with the number of hotel rooms to be cleaned. This is due to the presence of the standard provisions the amount of labor which performing a particular task. This problem resulted in less maximal work of housekeeping employees and non-performance of work efficiency in order to increase the marketability of the room. Therefore, measurement of workload needs to be redone to determine the number of employees who actually needs.

The purpose of this research is to determine how much the workload given to roomboy and labor productivity in the Housekeeping Department roomboy New Idola Hotel Jakarta. Furthermore to describe the ideal number roomboy needs by measuring the workload in the Housekeeping Department New Idola Hotel Jakarta.

\section{REFERENCES}

Mangkuprawira, S. (2003). Manajemen Sumber Daya Manusia Strategik. Jakarta: PT. Ghalia.

Rumekso.(2009). Housekeeping Hotel. Yogyakarta: Andi Offset.

Sugiarto, Endar dan Sri Sulartiningrum. (2003). Pengantar Akomodasi dan Restoran. Jakarta: PT. Gramedia Utama. 
Sulastiyono, Agus. (2011). Manajemen Penyelenggaraan Hotel. Bandung: Alfabeta.

Suwatno, Juni \& Doni Priansa. 2011. Manajemen SDM dalam Organisasi Publik dan Bisnis. Bandung: Alfabeta.
Tulus, Agus. 1996. Manajemen Sumber Daya Manusia. Jakarta: PT. Gramedia Pustaka Utama. 